Tetiana Sovik,

PhD (Candidate of Pedagogical Sciences), associate professor, Department of Musical Arts,

Kamianets-Podilskyi Ivan Ohiienko National University, 61, Ohiienka Str., Kamianets-Podilskyi, Ukraine

\title{
TECHNOLOGICAL SKILLS AS A COMPONENT OF MUSIC AND AESTHETIC COMPETENCE OF FUTURE PRIMARY SCHOOL TEACHERS
}

New requests of modern primary school education cause the revision of requirements to professional competence of future teachers. Among other competencies the actual one is musical and aesthetic competence of a primary school teacher as development of creative potential of a personality of a pupil depends on it. Musical and aesthetic competence includes a number of skills (value and motivational, cognitive, technological, practice and activity). The technological skills are of particular importance, as they accumulate the above-stated skills-mastering knowledge, skills and abilities according to indicators: technique of teaching the perception of a musical work; technique of teaching singing; technique of teaching the basics of musical literacy; technique of teaching children to play musical instruments; technique of teaching musical and rhythmic movements; technique of development of primary school pupils' creative abilities. For a more differentiated approach in the assessment of skills and abilities of students, there have been developed a three-level qualitative characteristic. Carrying out measurements on these indicators helped to trace the level of formation of technological skills of future primary school teachers, to reveal shortcomings and the need for improvement of pedagogical conditions of their formation.

Keywords: technological skills, musical and aesthetic competence, future primary school teachers.

\section{Introduction}

Scientists of the European Union countries (Austria, Belgium, Germany, Finland, the Netherlands) in different interpretations give the concept of "key skills". "In Austria scientists identify subject skills, personal skills, social skills, methodological skills. For implementation of a concept of competence in educational process pedagogical staff perform teaching on international basis, they are guided by team work, implement individualization and design line of work. In Belgium, the criteria of competence are multidimensionality, availability, clarity, and multifunctionality. Skills distribution is as follows: social skills, communicative skills, ability to work, skills in mastering a database of information and computer technologies, skills in problem solving, self-management and self-control, ability to think critically, act, and so on. Scientists of Finland identify informative skills, ability to operate in changing conditions, social skills, personal skills, creative skills, pedagogical and communicative skills, administrative skills, strategic skills, ability to operate in parallel in different directions. In Germany, intellectual knowledge, knowledge which can be applied, educational skills, methodological or instrumental key skills, social skills, value orientations are identified. In the Netherlands, competence is understood as a capability for self-training, confidence and ability to choose the directions of development, ability to act in various situations, to apply various alternatives to perform an action, to play different roles, ability to solve problems, to negotiate the options of one's choice, to take into account different circumstances, to respect others, to be a loyal person, ability to cooperate and find creative solutions" [2].

The aim of the article is to analyze the essence of technological skills (indicators) as a component of musical and esthetic competence of future primary school teachers and to develop the levels of its formation.

\section{Discussion}

Skills are understood as an objective category of socially recognized level of knowledge and skills in a particular field of human activity as an abstract medium (L. Pushkar, R. Savchenko, I. Sokolova and others).

Competence is the mastering of certain skills by a person including personal attitude to the subject of activity. So, skills are understood as the pledged requirement, a regulation of educational training of a person (pupil), and competence - as its created personal qualities and experience of activities [3]. According to the main aims of general education, the main types of pupil's activities, allowing him/her to acquire social experience, to create skills of life and practical activities in society, the list of key skills is defined. The main types of skills include:

- value and semantic skills which are connected with value notions of a pupil, him/her capability to orientation in life, understanding of his/her place in it, the choice of target and semantic guidelines for the actions and acts, for decision making. Educational development of a pupil and his/her life in society in general depends on its formation;

- general cultural skills as a range of issues in which a pupil has to be well informed, have knowledge and experience of a certain activity (features of culture: national and universal; cultural bases of family and social 
events and traditions, a role of science and religion in human life; skills of the household sphere and cultural leisure activities);

- educational and cognitive skills as a set of a pupil's skills in the field of independent cognitive activity: knowledge, skills and abilities of commitment, planning, analysis, reflection, self-learning of educational and cognitive activity. Requirements of the corresponding functional literacy are reflected in it: the ability to differentiate facts and speculations, possession of measuring skills, the use of various learning methods;

- information skills, which are connected with formation of ability of independent search of the analysis, selection of necessary information and it is directed to transformation, saving and demonstration of it. These skills provide pupils' abilities to work with information blocks, which make up school subjects and educational areas and so on;

- communicative skills, which include mastery of languages and ways of interaction with people, skills to work in a group. A pupil should be able to introduce him/herself, write a letter, an application form, to formulate a question, to debate;

- social and labor skills as mastering of knowledge and experience in civil and social activities, in the social and labor sphere, in the sphere of family relations, in matters of economics and law and in professional selfdetermination;

- skills of personal self-determination, which are aimed at mastering the ways of physical, spiritual and intellectual self-development, emotional self-control and self-support. It is connected with continuous selfknowledge, development of necessary personal qualities, formation of psychological literacy, culture of thinking and behavior. These skills include personal hygiene, care about one's own health, internal ecological culture, a complex of qualities related to the basics of safe life [5].

Based on the theoretical analysis of psychological and pedagogical literature (V. Vvedenskyi [1], A. Hura, A. Zhelezniakov, L. Zanin, N. Kuzmin [4], T. Leontiev, A. Markov, N. Menshykov, V. Mizherykov, N. Nikitina, etc.) we have determined musical and esthetic competence of future primary school teachers as the gained experience, which integrates elementary musical knowledge, practical skills, development of musical capabilities in the course of practical activities and an orientation on implementation of musical and esthetic education at primary school.

Components of musical and esthetic competence of future primary school teacher are the skills: value and motivational (a musical and esthetic outlook, interest in musical disciplines, orientation on musical and esthetic work at school), cognitive (theoretical knowledge of musical disciplines), technological (possession of knowledge of a technique of musical education at primary school: the ability to choose the forms and training methods, corresponding to content of program material of primary school) and practice and activity (use of musical knowledge, skills in practice; activization of the gained experience (perception of a piece of music listening and the ability to assess the listened works, a capability for rhythmic improvisation and dramatization of vocal works, playing children's musical instruments).

An important component of musical and esthetic competence of future primary school teachers is technological skills, which contain requirements to knowledge of a technique of musical education (matching of the corresponding forms and training methods, matching of musical material, etc.) of future teacher of musical art - the possession of a general technique of musical education (primary and high school).

Only theoretical knowledge of a particular discipline, not backed up by the knowledge of its technique can not be a teacher competence. For a more differentiated approach in the assessment of skills and abilities of students we have developed a three-level qualitative characteristic.

Technological skills accumulate possession of knowledge and abilities from the following techniques:

- technique of teaching the perception of a musical work;

- technique of teaching singing;

- technique of teaching the basics of musical literacy;

- technique of teaching children to play musical instruments;

- technique of teaching musical and rhythmic movements;

- technique of development of primary school pupils' creative abilities.

Let us consider the qualitative characteristic on each indicator.

The high level of mastering the technique of teaching the perception of a musical work synthesizes knowledge of a technique of listening to music at primary school, the ability to transfer knowledge in the form most corresponding to the age features of pupils; knowledge of a technique of musical perception development of primary school children. The average level of mastering the technique of teaching the perception of a musical work includes sufficient knowledge of a technique of listening to music at primary school; attempts to consider age features of primary school pupils; selective knowledge of methods of musical perception of primary school age children. The low level of mastering the technique of teaching the perception of a musical work is characterized by insufficient knowledge of the procedure for listening to music at primary school; lack of ability to transfer knowledge pupils; ignoring age characteristics of pupils in the explanation of a piece of music; inability to apply methods of development of musical perception of primary school age children.

The high level of mastering the technique of teaching singing is characterized by excellent knowledge of this technique; knowledge of age features of children's voices; knowing a procedure of formation of vocal skills; ability to identify a child's voice range, to choose an appropriate repertoire. The average level of mastering the technique of teaching singing is characterized by insufficient basic knowledge of this technique; knowledge of age features of children's voices; partial knowing of a procedure of formation of vocal skills; identification of a child's voice range and selection of 
an appropriate repertoire takes place with the help of a teacher. The low level of mastering the technique of teaching singing is characterized by intuitive knowledge about this technique; insufficient knowledge of age features of children's voices; failure to reveal a child's voice range and to select an appropriate repertoire.

The high level of mastering the technique of teaching the basics of musical literacy is characterized by excellent knowledge of the technique of teaching music basics; independent selection of necessary musical and theoretical and practical material; independent teaching of educational material according to the pupils' age features. The average level of mastering the technique of teaching the basics of musical literacy is characterized by sufficient knowledge of this technique; partial selection of necessary musical and theoretical and practical material; insufficient accounting of pupils' age features; uncertainty during the presentation of educational material. The low level of mastering the technique of teaching the basics of musical literacy is characterized by the minimum knowledge of this technique; the need for assistance in selection of the necessary musical and theoretical, and practical material; inability to present material consistently, partial accounting of pupils' age features.

The high level of mastering the technique of teaching children to play musical instruments is characterized by good knowledge of this technique; taking into account the age features of pupils' development, training in playing children's musical instruments; independent selection of the musical repertoire. The average level of mastering the technique of teaching children to play musical instruments is characterized by sufficient knowledge of this technique; partially independent teaching playing musical instruments to children's, taking into account pupils' age features; need for a teacher's consultation while selecting musical repertoire. The low level of mastering the technique of teaching children to play musical instruments is characterized by superficial knowledge of this technique; inability to provide the teaching of playing an instrument independently (only with a teacher's help), partial accounting of pupils' age features; insufficient ability to choose the musical repertoire, to draw the score.

The high level of mastering the technique of teaching musical and rhythmic movements is characterized by high knowledge of this technique; independence while teaching the elements of musical and rhythmic exercises, dance, taking into account age features of pupils' development; independent matching of music to an exercise, a dance, a game; a capability to choreograph a simple dance. The average level of mastering the technique of teaching musical and rhythmic movements is characterized by partial knowledge of this technique; the need for teacher's help while teaching the elements of musical and rhythmic exercises, dances; partially independent selection of music to an exercise, a dance, a game; feeling of uncertainty to choreograph a simple dance. The low level of mastering the technique of teaching musical and rhythmic movements is characterized by the minimum knowledge of this technique; dependence while teaching the elements of a dance, a game, an exercise (only with a teacher's help), not taking into account the child's age features of development; inability to mach music to a dance, an exercise, a game; the need for a teacher's help to choreograph a simple dance.

The high level of mastering the technique of development of primary school pupils' creative abilities is characterized by good knowledge of this technique: methodically correct using of various kinds of tasks in musical and aesthetic creativity (vocal, instrumental improvisation, staging with improvisation elements), which are feasible for children of this age, carrying out musical games independently). The average level of mastering the technique of development of primary school pupils' creative abilities is characterized by sufficient knowledge of this the technique: partially independent using of various kinds of tasks in musical and aesthetic creativity (vocal, instrumental improvisation, staging with improvisation elements), which are feasible for children of this age; partially independent carrying out musical games. The low level of mastering the technique of development of primary school pupils' creative abilities is characterized by superficial knowledge of this technique: inability to use independently the types of tasks of musical and aesthetic creativity (vocal, instrumental improvisation, staging with improvisation elements), which are feasible for children of this age (teacher's help is required); need of a teacher's help while carrying out musical games.

\section{Conclusions}

Carrying out measurements on these indicators helped to trace the influence of the use of the developed teaching technique in the educational process (use of an integrated approach in teaching music theory with the musical editor "Finale", variability when testing the theoretical knowledge and the formation of musical skills (variation of test form of examination of theoretical knowledge of students with their immediate musical activities for each session) on the formation of students' skills to respond to music emotionally, as well as to enrich their musical experience and the nature of formation of musical and aesthetic competence. So, after check of theoretical knowledge of a certain subject each practical lesson turned into a minilaboratory, in which each student carried out a music lesson fragment: listening to a piece of music, a song lesson, teaching to play children's musical instruments, choreographing musical and rhythmic movements, holding a musical didactic game. This method of teaching is a kind of simulator for future teachers, because after studying the course, students have teaching practice at school, where they are given the opportunity to test their power, to apply their knowledge and skills.

Observation during the experiment, analysis of materials of testing production of pedagogical practice showed that students with a high level of technological skills differ, as a rule, in productive nature of musical and aesthetic activity, which is shown in their creative selfexpression, which is characterized by an interest in knowledge, speed and depth mastery of knowledge, skills and 
abilities, great efficiency, the development of perception, observation, memory and imagination, the ability to direct attention, search for more rational and simple techniques, methods for the solution of the tasks. They have formed steady attention, interest in music. They know the school repertoire and are able to mach it according to a theme of the lesson, to construct the work on a piece of music independently, they show independence and initiative in selection of the repertoire for musical events and entertainments in extracurricular activities, are able to apply the musical abilities and knowledge for work with pupils.

The characteristic of students with the average level of mastering the technological skills is as follows: situational productivity in musical and aesthetic activity, partial independence in organization of work on a piece of music (in the selection and evaluation of the works they are guided by intuition, pay attention mainly to external signs). In selection of methods and techniques for carrying out a specific type of musical activity (listening to

\section{REFERENCES}

1. Vvedenskiy, V. N. (2003). Modelirovaniye professionalnoy kompetentnosti pedagoga [The modelling of professional competence of a teacher]. Minsk: Pedagogika [in Russian].

2. Kozhevnikov, V. (2008). Poniattia "kompetentnist" u pedahohitsi [The concept of "skills" in pedagogy]. Retrieved from: http://osvita.ua/school/theory/1964/ [in Ukrainian].

3. Volkova, N. P. (Ed.). (2003). Konspekt lektsii [Lecture notes]. Kyiv: Vydavnychyi tsentr «Akademiia» [in Ukrainian].

\section{ЛІТЕРАТУРА}

1. Введенский В.Н.Моделирование профессиональной компетентности педагога // Педагогика / В. Н. Введенский - №10. - 2003. - С. 51-55.

2. Кожевніков В. Поняття «компетентність»у у педагогіці [Електронний ресурс] / В. Кожевніков. Режим доступу : http://osvita.ua/school/theory/1964.

3. Конспект лекцій. Педагогіка (за ред. Н. П. Волкової) - Київ : Видавничий центр «Академія», 2003. - 576 c. music, learning a song, playing children's musical instruments, learning musical and rhythmic movements, carrying out musical and didactic game), independent work and understanding the opportunities of its use in work with primary school pupils; leading questions, a piece of advice of a teacher are necessary for them. Such students are confident in their abilities; often try to fill the gaps in knowledge of a technique of musical education with knowledge of other disciplines.

Students with the low level of technological skills are characterized by reproductive musical and aesthetic activity, insufficient knowledge of self-study methods, inability to transform pedagogically the acquired knowledge, to finish the started activity, a narrow musical outlook, lack of initiative, uncertainty. The specified shortcomings have caused tendency of such students to be guided in the activity only by ready samples and instructions of a teacher. They cannot conduct a fragment of a methodically correct lesson of musical art.

4. Kuzmina, N. V. (1990). Professionalizm lichnosti prepodavatelya $i$ mastera proizvodstvennogo obucheniya [Professionalism of personality of a teacher and master of vocational training]. Moscow: Vysshaya shkola [in Russian].

5. Pepaheichenko, V. (n.d.). Kliuchovi kompetentnosti vchytelia. Shkola molodoho dyrektora [Key competence of a teacher. School for a young director]. Retrieved from: http://vovse.net/syd/theory/85-klyuchov-komponentikompetentnost-vchitelya.html/ [in Ukrainian].

4. Кузьмина Н. В. Профессионализм личности преподавателя и мастера производственного обучения / Н. В. Кузьмина. - Москва : Высш. шк., 1990. - 119 с.

5. Пепагейченко В. Ключові компетентності вчителя. Школа молодого директора [Електронний pecypc] / В. Пепагейченко // Відкритий урок: розробки, технології, досвід. - Режим доступу : http://vovse.net/syd/theory/85-klyuchov-komponentikompetentnost-vchitelya.html.

Тетяна Віталіївна Совік, кандидат педагогічних наук, доцент кафедри музичного мистецтва, Кам'янеиь-Подільський національний університет імені Івана Огієнка, вул. Огієнка, 61, м. Кам'янеиь-Подільський, Украӥна

\section{ТЕХНОЛОГІЧНА КОМПЕТЕНЦІЯ ЯК СКЛАДОВА МУЗИЧНО-ЕСТЕТИЧНОЇ КОМПЕТЕНТНОСТІ МАЙБУТНІХ УЧИТЕЛІВ ПОЧАТКОВОЇ ШКОЛИ}

Нові запити сучасної початкової шкільної освіти зумовлюють перегляд вимог до професійної компетентності майбутніх учителів. Серед інших компетентностей актуальною є музично-естетична компетентність учителя початкової школи, оскільки саме від неї залежить розвиток творчого потенціалу особистості учня. Мета дослідження - проаналізувати сутність технологічної компетенції як складової музично-естетичної компетентності майбутніх учителів початкової школи та розробити рівні її сформованості. Музично-естетична компетентність включає ряд компетенцій (ціннісно-мотиваційну, когнітивну, технологічну, практико-діяльнісну). Особ- 
ливого значення набуває технологічна компетенція, оскільки акумулює вищевказані компетенції - володіння знаннями, навичками та вміннями за показниками: методика навчання сприйняття музичного твору; методика навчання співу; методика навчання основам музичної грамоти; методика навчання гри на дитячих музичних інструментах; методика навчання музично-ритмічним рухам; методика розвитку творчих здібностей учнів початкової школи. Для більш диференційованого підходу в оцінюванні вмінь і навичок студентів нами розроблена трирівнева якісна характеристика кожного показника. Спостереження впродовж експерименту, аналіз матеріалів перевірки виробничої педагогічної практики показали, що студенти з високим рівнем володіння технологічною компетенцією відрізняються, зазвичай, продуктивним характером музично-естетичної діяльності, яка виявляється у їхньому творчому самовираженні, для якого характерним є інтерес до пізнання, швидкість і глибина оволодіння знаннями, навичками та вміннями, велика працездатність, розвинене сприйняття, спостережливість, пам'ять і уява, вміння спрямовувати увагу, пошук більш раціональних і простих прийомів, методів для розв'язання поставлених завдань. Характеристика студентів із середнім рівнем володіння технологічною компетенцією така: ситуаційна продуктивність у музично-естетичній діяльності, часткова самостійність в організації роботи над музичним твором (у виборі й оцінюванні твору керуються інтуїцією, звертають увагу переважно на зовнішні ознаки). Для студентів із низьким рівнем володіння технологічною компетенцією характерним $\epsilon$ репродуктивна музично-естетична діяльність, недостатнє знання методики самостійної роботи, невміння педагогічно трансформувати набуті знання, самостійно довести почате до кінця, вузький музичний кругозір, безініціативність, невпевненість. Проведення замірів за вказаними показниками допомогло простежити рівень сформованості технологічної компетентності майбутніх учителів початкової школи, виявити недоліки та потребу в удосконаленні педагогічних умов iï формування.

Ключові слова: технологічна компетенція, рівень, показник, музично-естетична компетентність, майбутній учитель початкової школи.

Submitted on February, 3, 2017

Reviewed by Doctor of Pedagogy V. Labunets

УДК: 37.035.6(477)(091)"18/19":908

https://doi.org/10.24195/2414-4665-2017-2-4

Orcid.org/0000-0002-2215-3994

Марія Миронівна Чепіль, доктор педагогічних наук, професор, завідувач кафедри загальної педагогіки та дошкільної освіти, Дрогобицький державний педагогічний університет імені Івана Франка вул. Франка, 24, м. Дрогобич, Україна

\section{ДИТИНА ЯК СУБ'ЄКТ ВИХОВАННЯ У ПЕДАГОГІЧНІЙ СПАДЩИНІ СОФІЇ РУСОВОї}

У статті розкрито погляди С. Русової на виховання дитини, головні фактори ї̈ формування та розвиток. Акцентовано увагу на необхідності орієнтації на особистість, на розвиток ї̈ здібностей, природних сил $i$ талантів у діяльності освітніх установ. Розкрито мету виховання, зміст освіти та чинники формування особистості, педагогічні засоби й методи, щзо сприяють найефективнішому розвиткові природних задатків $i$ здібностей індивідума. Особистість виникає у проиесі діяльності і розвивається в суспільних умовах життя. Кожна дитина народжується як продукт об'єднаного біологічного і антропологічного процесу.

Ключові слова: дитина, виховання, вихователь, дитячий садок, школа, Софія Русова.

Постановка проблеми. Розвиток педагогічної науки в Україні неможливо уявити без вивчення і осмислення вітчизняного та світового виховного досвіду. В історії розвитку історико-педагогічного процесу простежується певна логіка виникнення і змін педагогічних парадигм, що неодмінно передбачає виникнення і розвиток нових концепцій виховання, нових моделей дошкільних закладів і шкіл. Кінець
XIX - початок XX ст. характеризується відродженням української нації, зростанням активності прогресивної інтелігенції у змаганнях за освіту, науку, культуру. Приклад життя і творчості, ідеї та погляди педагогівпросвітителів, які жили і творили у цей період, їхня педагогічна спадщина, заборонена чи замовчувана на теренах Радянського Союзу, не залишені непоміченими як іiі сучасниками, так і дослідниками за його ме- 